\title{
HVMANITAS
}

\section{Fontes para o estudo do direito ático}

\section{Autor(es): Leão, Delfim F.}

Publicado por: Imprensa da Universidade de Coimbra

URL persistente:

URI:http://hdl.handle.net/10316.2/27398

DOI:

DOI:http://dx.doi.org/10.14195/2183-1718_64_6

Accessed : $\quad$ 26-Apr-2023 13:15:23

A navegação consulta e descarregamento dos títulos inseridos nas Bibliotecas Digitais UC Digitalis, UC Pombalina e UC Impactum, pressupõem a aceitação plena e sem reservas dos Termos e Condições de Uso destas Bibliotecas Digitais, disponíveis em https://digitalis.uc.pt/pt-pt/termos.

Conforme exposto nos referidos Termos e Condições de Uso, o descarregamento de títulos de acesso restrito requer uma licença válida de autorização devendo o utilizador aceder ao(s) documento(s) a partir de um endereço de IP da instituição detentora da supramencionada licença.

Ao utilizador é apenas permitido o descarregamento para uso pessoal, pelo que o emprego do(s) título(s) descarregado(s) para outro fim, designadamente comercial, carece de autorização do respetivo autor ou editor da obra.

Na medida em que todas as obras da UC Digitalis se encontram protegidas pelo Código do Direito de Autor e Direitos Conexos e demais legislação aplicável, toda a cópia, parcial ou total, deste documento, nos casos em que é legalmente admitida, deverá conter ou fazer-se acompanhar por este aviso.

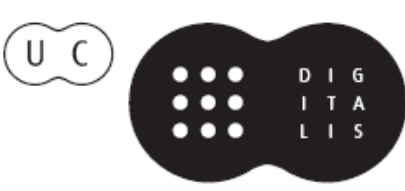


humanitas

\section{Vol. LXIV \\ 2012}

IMPRENSA DA UNIVERSIDADE DE COIMBRA

COIMBRA UNIVERSITY PRESS 


\title{
FONTES PARA O ESTUDO DO DIREITO ÁTICO
}

\author{
DeLFIM F. LeÃo \\ Universidade de Coimbra \\ leo@fl.uc.pt
}

\begin{abstract}
Resumo
Começando por um enquadramento relativo ao lugar ocupado pelos estudos de direito grego antigo nos curricula universitários ocidentais, propõe-se uma reflexão sobre o tipo de saberes que é necessário conjugar para se obter um conhecimento mais amplo da lei na antiguidade clássica. Assim, a um conjunto de fontes que se repartem pela epigrafia, papirologia e, em sentido lato, por toda a literatura (desde a historiografia ao teatro, e desde os escritos filosóficos à prática forense), deve corresponder um esforço conjunto resultante da articulação entre historiadores, juristas, filólogos, epigrafistas e papirólogos. Este carácter variado das fontes para o estudo do direito grego (em particular o ático) corresponde, por outro lado, à forma como a cidadania e a administração da justiça eram praticadas no sistema da pólis - princípios que são também objecto de reflexão neste estudo.

Palavras-chave: lei, direito ático, administração da justiça, democracia antiga.

Abstract

The paper starts with a short description of the status attributed to studies on ancient Greek law in the curricula of western universities, discussing the kind of knowledge that is necessary to combine in order to reach a deeper understanding of law in classical antiquity. Thereby, to the inquiry stimulated by an amount of sources distributed by epigraphy, papyrology and, in a wide sense, by the literature as a whole (from historiography to theatre, and from philosophical writings to forensic speeches), answers should be found in articulating the research made by historians, jurists, philologists, epigraphists, and papyrologists. The wide-range character of the sources available to the study of Greek law (in particular Athenian
\end{abstract}


law) corresponds, on the other side, to the way citizenship and the administration of justice were promoted within the polis' system - a topic that is also object of discussion in this study.

Key-words: law, Attic law, administration of justice, ancient democracy.

\section{O carácter 'marginal' dos estudos sobre direito grego}

Apesar de algumas notáveis excepções, a presença do direito grego nas universidades europeias é tradicionalmente muito marginal, ainda que haja uma comunidade internacional bastante coesa e bem definida que se dedica à pesquisa sobre a lei na Grécia antiga. Sinal disso mesmo é a chamada Gesellschaft für griechische und hellenistische Rechtsgeschichte, criada informalmente por H. J. Wolff, e que, desde 1971, realiza congressos internacionais regulares (os chamados Symposia), dedicados especificamente a esta área do saber. Em anos mais recentes e sobretudo no mundo anglo-saxónico, têm-se multiplicado os estudos que incidem sobre a lei na Grécia antiga, não raro combinados com abordagens de carácter histórico, político e ainda sociológico. Expressão deste interesse acrescido pelo fenómeno jurídico helénico é também o lançamento, a partir de 1998, da revista Dike (publicada pela Università degli Studi di Milano, por iniciativa de E. Cantarella e A. Maffi), que cultiva aliás um relacionamento muito próximo com a sociedade antes referida. Mais recentemente ainda, passou a realizar-se, nos intervalos dos Symposia promovidos pela Gesellschaft, uma iniciativa conhecida por "International Meeting of Young Historians of Greek Law", cuja segunda edição se realizou em Setembro de 2010, em Atenas. ${ }^{1}$ Portugal não ficou alheio a este dinamismo, embora o primeiro volume dedicado especificamente a questões de direito grego fosse publicado somente em 2004, reunindo a participação de uma equipa internacional de quinze especialistas, num livro coordenado por Livio Rosseti, Maria do Céu Fialho e pelo redactor destas reflexões: Nomos. Direito e sociedade na Antiguidade Clássica/Derecho y Sociedad en la Antigüedad Clásica

1 Para uma sinopse destas iniciativas científicas e dos vários tipos de abordagem feita, vide Maffi (2004) 33-35. 
(Coimbra e Madrid). ${ }^{2}$ Desde há alguns anos, a área de Estudos Clássicos da Universidade de Coimbra passou a contemplar um seminário específico sobre Direito e Sociedade no Mundo Antigo, no curso de Doutoramento em Mundo Antigo, criado já ao abrigo da reforma curricular decorrente do processo de Bolonha. Há, portanto, algumas razões de peso para crer que, ao longo dos próximos anos, o direito grego venha a atrair uma atenção crescente também no espaço lusófono, contrariando assim um cenário anterior em que, mesmo nas Faculdades de Direito, esta matéria era aflorada somente como introdução ao direito romano, em especial para analisar a tradição, difundida já na Antiguidade, segundo a qual a base do sistema legal romano (a Lei das XII Tábuas) se teria inspirado no código de um dos maiores legisladores gregos e também o primeiro poeta ático: Sólon. ${ }^{3}$

Ainda no âmbito destas considerações preliminares, é revelador constatar que, além de juristas familiarizados com a jurisprudência romana, o direito grego tem atraído igualmente a atenção de historiadores, filólogos, epigrafistas e papirologistas. Esta realidade compósita, que continua ainda a motivar alguma discussão sobre o perfil mais correcto de um estudioso destas matérias, acaba por constituir um indício da própria natureza variada das fontes disponíveis e do tipo de abordagens que estimulam, aspecto sobre o qual importa reflectir um pouco mais em pormenor.

\section{A natureza díspar das fontes}

A consideração de problemas jurídicos obedece, com muita frequência, à necessidade sentida pelos investigadores de esclarecer determinadas especificidades de natureza histórica, política, literária ou ética, e não tanto para analisar o fenómeno jurídico em si. Esta situação não se revela muito diferente mesmo em países onde é maior a tradição e o número de pessoas que se dedicam ao estudo da lei grega. Em boa verdade, uma abordagem orientada nesses moldes afigura-se perfeitamente legítima, na medida em que o material existente para o conhecimento do direito grego é também, essencialmente, de carácter histórico, político, literário ou filosófico. Com

2 Em Leão (2001), havia já vários capítulos (II.5 e II.6) dedicados especificamente à problemática do direito, em especial às leis de Sólon. Muito recentemente, foi dado mais um passo na abordagem legal do texto literário, de novo envolvendo uma equipa internacional, onde figuram vários investigadores portugueses; vide Harris, Leão e Rhodes (2010).

3 E.g. Tito Lívio, 3.31. Sobre esta questão, vide o extenso artigo de Campos (2004). 
efeito e como adiante se verá, os testemunhos principais são facultados muitas vezes de forma dispersa, na historiografia (Heródoto, Atidógrafos, Tucídides), no próprio teatro (os trágicos, Aristófanes e, em menor grau, os representantes da comédia nova) e em obras de carácter político-filosófico (alguns diálogos de Platão e, em especial, a Constituição dos Atenienses, a Política e a Retórica de Aristóteles). A estes elementos de natureza literária produzidos ao longo da Época Clássica, há a acrescentar a informação determinante fornecida pelos Oradores Áticos, sobretudo os discursos forenses produzidos em finais do séc. $\mathrm{V}$ e ao longo de todo o séc. IV, para além de contributos bastante posteriores, como as obras de Plutarco, Diógenes Laércio ou a antiquária. ${ }^{4}$

$\mathrm{O}$ facto de a matéria legal se reflectir nas mais diversas manifestações culturais e artísticas da pólis constitui, por conseguinte, uma das consequências do exercício activo da cidadania, que exige de cada polites uma intervenção directa (e de certa maneira amadora) nos assuntos da comunidade. Contudo, esta realidade não conduz necessariamente à ausência de pensamento jurídico entre os Gregos, como por vezes se sustenta. Com efeito, não só tal afirmação se afigura excessiva à luz da informação conservada, como há inclusive indícios relativamente seguros de que poderá ter existido uma literatura jurídica autónoma. ${ }^{5}$ Ainda assim, na maioria dos casos tudo o que se conserva são os títulos de obras hoje perdidas, pelo que dificilmente se conseguirá esclarecer se a perspectiva nelas adoptada consistiria numa discussão de natureza legal ou antes numa análise política ou histórico-constitucional. ${ }^{6}$ De facto, um título chamativo não é garantia

4 Menos abundantes, embora com um valor apreciável, são os dados fornecidos por fontes arqueológicas e epigráficas.

5 A este respeito, vide observações de Rossetti (1999), expandidas em (2004), embora acusem algum excesso de optimismo na forma de interpretar a parca informação fornecida pelas fontes em relação a obras hoje perdidas.

6 A título de exemplo, vide Diógenes Laércio (5.42-50), que dá um impressionante rol de títulos atribuídos a Teofrasto, onde se encontra (5.44) um promissor trabalho sobre Leis organizadas por ordem alfabética, em vinte e quatro volumes, logo seguido por um Resumo de leis, em dez volumes. Rossetti (2004), 56, calcula que os trabalhos de Teofrasto sobre matéria legal ascendessem a quarenta volumes ou até mais. Todd (1993), 39-40, é mais contido na análise, mas não deixa de reconhecer, a propósito da primeira das obras referidas que (39) "it apparently discussed not just Athenian laws, but also those of other Greek poleis; this would have filled a massive gap in our knowledge, and would have enabled us to see whether Theophrastos conceived Greek law as a unity or was simply prepared to accept material from any community that he could get his hands on". 
de que se estaria perante um tratado de jurisprudência, como se pode ver pelo caso das Leis de Platão, trabalho que, tendo embora sido conservado na íntegra, acaba por ter um impacto bastante reduzido no estudo factual da lei grega, precisamente por causa da dificuldade em distinguir o que nele podem ser ecos da realidade histórica ou simples invenção de Platão. ${ }^{7}$ Em todo o caso, é indiscutível que escritos com alguma incidência em matéria legal despertaram um grande interesse no séc. IV a.C., especialmente entre os círculos peripatéticos. Basta recordar, a título de exemplo, que a Constituição dos Atenienses atribuída a Aristóteles era apenas uma das cento e cinquenta e oito politeiai, cuja recolha o Estagirita promovera no seio do Liceu. Por conseguinte, ainda que a experiência do direito grego não possa ombrear com a teorização desenvolvida pelos Romanos, também não será caso para sustentar que os Gregos não conseguiram de todo ultrapassar o estádio empírico da consciência jurídica. ${ }^{8}$

Um outro aspecto determinante na consideração destas matérias, ainda que nem sempre acautelado em termos de análise, reside na contingência de as fontes para o conhecimento do direito não possuírem todas o mesmo valor. $\mathrm{O}$ facto de uma disposição vir insistentemente atribuída a determinada época ou figura não constitui garantia inequívoca da sua autenticidade. É necessário ter em linha de conta a frequente presença de aproveitamentos ideológicos, da propaganda política, de erros de percepção motivados pelo confronto com realidades bastante diferentes e dos quais o autor do testemunho não está, muitas vezes, sequer consciente. É no concurso destes factores que deve ser avaliada, por exemplo, a tarefa de revisão legislativa iniciada após o golpe dos Quatrocentos, em 411, e concluída depois da segunda restauração democrática de 403 , bem como o desenvolvimento do tema da patrios politeia, que influenciou boa parte dos autores do séc. IV e dos que deles se serviram como Mittelquelle. O risco de incorrer em simples especulação aumenta, aliás, ao usar de maneira acrítica fontes que podem estar separadas por muitos séculos, como ocorre quando se procura reconstituir os avanços do direito na Época Arcaica, à luz de informação veiculada por Plutarco, Diógenes Laércio ou pela antiquária. ${ }^{9}$

7 Todd (1993) 40.

8 Conforme defende, entre outros, Biscardi (1982) 13.

9 Para um exemplo das implicações decorrentes desse exercício crítico, aplicado a aspectos das leis de Sólon com incidência na área familiar, vide Leão (2005). 
Por último, importa ainda chamar a atenção para o facto de que, na Grécia da Época Arcaica ou Clássica (período sobre o qual incide esta reflexão), não existia propriamente um sistema legal grego que aplicasse a justiça de maneira uniforme. A experiência política da Hélade fazia de cada pólis uma célula autónoma, cuja identidade se definia através de uma série de realizações próprias e distintivas, como o dialecto, a divindade políade, a moeda (quando era emitida) e também a própria constituição, de cuja natureza dependia toda a estrutura legislativa. Neste sentido, será caso para reconhecer alguma pertinência à tese de que o direito variava com cada um das póleis (tot iura quot ciuitates). Para dar apenas um exemplo, em Atenas, um homem poderia desposar, dentro da esfera legal, a sua meia-irmã se com ela partilhasse o mesmo pai, mas não a mesma mãe; em Esparta, dava-se exactamente a situação contrária. ${ }^{10}$ Não obstante esta contingência, de que é necessário estar bem ciente, as várias cidades gregas não deixavam de partilhar um denominador jurídico comum que era a essência do próprio sistema da pólis. De resto, os Gregos tinham bem presente essa noção de identidade cultural e cívica, que lhes servia, em última análise, de traço distintivo em relação a outros povos. ${ }^{11}$ Ainda assim, há uma grande desproporção entre os dados disponíveis para o caso de Atenas e para as restantes póleis, situação que espelha, em boa verdade, a própria supremacia política e cultural da Ática dentro do mundo helénico. Esta realidade acaba por determinar a orientação dos estudos, que dependem, naturalmente, da natureza das fontes existentes. Entre essas fontes, adquirem especial importância os discursos forenses, produzidos em especial ao longo do séc. IV. No entanto, esses discursos podem apresentar uma visão distorcida da realidade, já que a primeira preocupação de um orador é convencer o colectivo de dikastai da justeza das suas posições, ainda que isso implique uma eventual diluição da verdade objectiva dos

10 Cf. Demóstenes, 57.20; Plutarco, Them. 32.2, para o caso ateniense. O único testemunho para a variante espartana é Fílon de Alexandria, De Spec. Leg. 3.22. Vide Harrison (1968-1971) I.21-24; MacDowell (1986) 82; Carey (1997) 2 e n. 1.

11 Como salienta Biscardi (1982) 8-9 e 21. Essa realidade é de resto muitas vezes sustentada nas fontes, encontrando em Heródoto uma expressão paradigmática, na forma como define as características do conceito de 'ser grego' ou de Hellenikon (8.144.2). 'partilhamos o mesmo sangue e a mesma língua, temos em comum os templos dos deuses e os altares, os

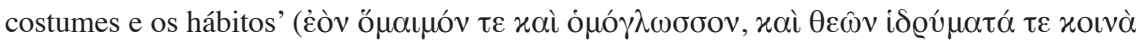

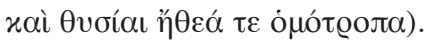


factos. Justifica-se, por isso, tecer algumas reflexões sobre certos aspectos da prática forense, antes de proceder à sistematização da tipologia das fontes.

\section{O funcionamento dos tribunais áticos na Época Clássica}

A correcta apreciação de um discurso sob o ponto de vista legal obriga a conhecer algumas das peculiaridades do funcionamento dos tribunais, que ajudam a justificar, de resto, o interesse do cidadão ateniense por questões jurídicas, tantas vezes espelhadas nas obras literárias, como ilustram de forma paradigmática as Vespas de Aristófanes. Ora uma forma de esclarecimento das peculiaridades do sistema judicial ateniense será recorrer à comparação, em termos latos, com a prática actual. ${ }^{12} \mathrm{Na}$ sociedade moderna, é usual que as partes em litígio assumam um papel relativamente pequeno na condução de um processo. Rega geral, recorre-se aos serviços de um especialista (o advogado), que tomará a seu cargo a tarefa de analisar a natureza e exigências do pleito, de recolher e tratar o material e, finalmente, de fazer a apresentação em tribunal, procurando valorizar as suas provas e rebater as apresentadas pelo adversário. Quando há o recurso a testemunhas, são elas próprias a apresentar o depoimento, embora sujeitas às indagações dos representantes das partes envolvidas. Por último, o processo é faseado, de modo a permitir que cada prova seja testada por ambos os lados antes de se passar à seguinte.

Ora a realidade ateniense comportava importantes diferenças. Antes de mais, o método de apresentação consistia num discurso que se desenrolava de forma contínua durante o tempo estipulado, com a acusação a preceder a defesa. $\mathrm{O}$ orador fornecia directamente toda a informação que considerava importante, pelo que às testemunhas cabia somente corroborar as declarações já feitas. Por último, outro aspecto peculiar reside no facto de a prática corrente ditar que fosse o próprio litigante a apresentar o caso em tribunal. ${ }^{13}$ Quando este se não sentisse à vontade para o fazer, seria possível apelar ao apoio de um synegoros (à letra 'o que fala com' ou 'o que fala em vez de'), o qual, em princípio, deveria apresentar-se na qualidade de amigo ou parente. A sua intervenção poderia consistir simplesmente na formulação das alegações finais ou, pelo contrário, na condução do corpo do discurso, cabendo, neste caso, ao litigante somente uma breve introdução. Quando

12 Nesta sistematização, retomámos alguns elementos utilizados em Leão (2001) I.4.

13 Carey e Reid (1985), 6, consideram improvável que houvesse uma lei específica a determinar esse procedimento, que derivaria simplesmente da tradição. 
o litigante era menor, mulher ou estrangeiro, a utilização de um synegoros seria, de resto, a única possibilidade de que disporia. ${ }^{14}$

Mas quando o cidadão envolvido na acção judicial decidia apresentar pessoalmente o caso, as hipóteses ao seu dispor seriam basicamente três: fazer a sua própria investigação e preparação, valendo-se da experiência acumulada na observação de casos semelhantes e nas oportunidades criadas pela participação nos órgãos democráticos $;{ }^{15}$ estudar a techne rhetorike em manuais eventualmente disponíveis ou com algum mestre, embora esta opção estivesse limitada pela pressão do tempo; finalmente, recorrer aos serviços de um especialista, a quem poderia comprar um discurso ou parte dele, tentando, depois, decorá-lo e proferi-lo como se fosse seu. O especialista em questão era o logographos. A tradução do termo por 'redactor de discursos' não faz total justiça à função que desempenhava, pois o logógrafo era o correspondente mais próximo, na antiga sociedade ateniense, dos modernos advogados, já que se encarregava de todos os pormenores do discurso, com a única diferença de que deveria ser o cliente a proferi-lo. Se bem que este procedimento estivesse dentro da legalidade, a profissão de logógrafo era desaprovada pela opinião pública grega, contrária a todo o tipo de profissionalismo, especialmente quando este era pago, já que favorecia quem melhor pudesse custear tais serviços. ${ }^{16}$ Apesar dessa desconfiança, os logógrafos eram muito usados pelos litigantes, embora estes evitassem admiti-lo enquanto decorria o processo. Como indicador seguro da fortuna dessa actividade está o facto de quase todos os grandes oradores terem, em algum momento da sua vida, exercido o trabalho de logógrafo.

Uma das características mais marcantes do sistema legal ateniense consiste no facto de o caso ser submetido à apreciação de um painel de juízes ou jurados (dikastai) constituído por cidadãos não profissionais, aos quais se requeria, apenas, que tivessem a idade mínima de trinta anos, certamente porque a experiência e a maturidade eram consideradas necessárias. A natureza não-profissional e colectiva destes dikastai ${ }^{17}$ justifica que

14 Cf. Kennedy (1989) 87. Uma vez que o synegoros se apresentava como amigo ou parente, não deveria, em princípio, ser nem profissional nem levar dinheiro pela intervenção, embora haja indícios de que isso pudesse acontecer. Cf. Demóstenes, 21.112; [46].26; [51].16.

15 Entre os quais se encontravam, precisamente, os tribunais.

16 Cf. Platão, Phdr. 257c; Demóstenes, 32.31.

17 O número de dikastai variava desde duzentos e um elementos (para processos populares) até múltiplos de quinhentos (para processos públicos). Conspecto das condicionantes que acompanhavam um julgamento em Carey (1997) 5-7. 
pudessem ser usadas alegações e estratégias de argumentação que seriam proibidas nos tribunais contemporâneos, mas que a obra dos oradores áticos espelha de forma clara, como acontece com digressões, citação de poemas e de longos passos de obras teatrais. Verifica-se por vezes também a acumulação de normas e dados que, numa leitura mais atenta, mostram ter uma relação meramente marginal com o assunto em discussão, mas que ajudavam a produzir um determinado efeito no auditório, que deveria votar em boa parte movido pelas impressões que os discursos de acusação e defesa nele provocavam no momento em que eram proferidos. ${ }^{18}$ Isso não significa que os atenienses não procurassem proibir os desvios do assunto e os ataques pessoais aos adversários. O tribunal do Areópago era conhecido por ser particularmente exigente na questão da relevância das matérias, e há de resto suficientes indícios para crer que essa norma também seria globalmente aplicada nos restantes tribunais. ${ }^{19}$

\section{Fontes para o estudo do direito ático}

Um dos aspectos curiosos na jurisprudência grega consiste no facto de se poder encontrar informação sobre essa matéria em obras de todo o tipo, realidade que nos remete, como atrás se dizia (supra secção 2) para a natureza da participação na vida pública entre os Gregos. No caso ateniense, desde a criação das classes censitárias por Sólon até à instauração da democracia por Clístenes que a participação do cidadão na vida política foi conhecendo novos aperfeiçoamentos. O pagamento (misthos) pelo desempenho de funções públicas, introduzido por Péricles, constituiu o corolário natural dessa evolução, ao garantir que mesmo os cidadãos mais pobres poderiam despender algum do seu tempo com a pólis, já que a sua sobrevivência ficava assegurada pelo subsídio atribuído pelo Estado

18 Plutarco (De garr. 504c) narra um episódio que teria envolvido um dos discursos escritos por Lísias para um cliente. Este queixara-se ao orador do facto de ter achado o discurso admirável quando o lera pela primeira vez, mas que lhe começara a desagradar nas leituras subsequentes, ao que Lísias teria respondido, entre sorrisos, que os dikastai só teriam de ouvir o discurso uma vez - portanto na altura em que o efeito persuasor seria maximizado. Embora a narrativa deva ter uma origem anedótica, não deixa de ser elucidativa da forma como os tribunais atenienses funcionavam e da necessidade de impressionar o auditório, ainda que com técnicas que se revelariam menos seguras, se o discurso pudesse ser analisado mais detidamente.

19 Sobre esta questão, vide Rhodes (2004); Leão (2010) 52. 
nos dias em que se encontravam ao serviço da colectividade. Era assim garantida, embora com algumas limitações, a aplicação de um dos princípios fundamentais do regime democrático: a isocracia. Esta 'igualdade no acesso ao poder' era estimulada ainda por mecanismos como a colegialidade e, em especial, a rotatividade e a tiragem à sorte aplicadas à maioria dos cargos públicos, o que levava a que praticamente todo o cidadão ateniense acabasse por estar, em algum momento da sua vida, ao serviço da pólis. Ora uma experiência cívica assente nestes moldes leva a que problemas relacionados com a legalidade e a administração da justiça acabem por fazer parte da formação de qualquer polites. Não surpreende, por isso, que o interesse por estas matérias se reflicta de forma abundante na própria produção artística e literária.

No entanto, se isso é particularmente verdade para Atenas, não deixa de ser igualmente válido para o primeiro grande monumento literário produzido no mundo ocidental: os Poemas Homéricos. Com efeito, sem contar com outros elementos que aparecem ao longo da Ilíada e Odisseia, é particularmente significativa a longa ekphrasis dos motivos que decoram o escudo de Aquiles (Il. 18.478-608), a qual, sendo embora colocada por Hefestos no mundo dos heróis, é geralmente considerada um dos quadros de composição mais recente, constituindo, no seu conjunto, uma espécie de microcosmos da Grécia na primeira metade do séc. VIII. Numa das cenas apresentadas (Il. 18.497-508), refere-se o julgamento de um caso de homicídio, que constitui, por isso mesmo, o documento mais significativo para o conhecimento da lei nesse período recuado, pesem embora as muitas dúvidas relativas à interpretação do procedimento descrito. Que o desenvolvimento da lei e a aplicação da justiça se encontravam ainda num estádio embrionário mostra-o também a referência de Hesíodo, nos Trabalhos e Dias,

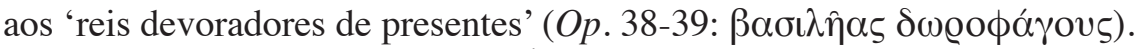
Para responder a essa situação, a Época Arcaica irá assistir, precisamente, a um esforço generalizado de criação de códigos de leis, que estimularão, por outro lado, a preocupação de os passar a escrito e de os disponibilizar em locais públicos. Isso mesmo terá acontecido, em Atenas, com Drácon e Sólon (sécs. VII-VI), cujas leis terão permanecido acessíveis durante a Época Clássica. ${ }^{20}$ Mais adiante se retomará essa questão, a propósito da

20 Sobre as circunstâncias de publicação e transmissão das leis dos primeiros legisladores atenienses através de kyrbeis e axones, vide Ruschenbusch (1966) 1-58; Stroud (1979); Leão (2001) 329-340. 
informação facultada pelas fontes epigráficas, mas importa desde já registar que a referência a essa legislação deixou vestígios em primeira mão também na literatura, como acontece quando Sólon se refere, nos poemas que ele mesmo compôs, à imparcialidade das leis que afirma claramente ter escrito (frg. 36.18-20 West):

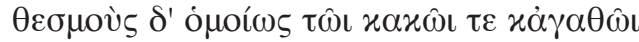

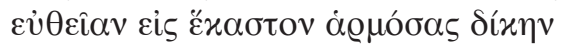

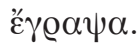

Leis, tanto para o vilão como para o nobre, que para cada um recta justiça ajustavam, escrevi.

Dentro ainda das fontes literárias indirectas, assumem um papel relevante a grande historiografia (especialmente Heródoto, Tucídides e Xenofonte), bem como os autores de crónicas locais (na caso de Atenas, os Atidógrafos), pela forma como discutem a natureza e autoria de determinadas leis ou registam o conteúdo de decretos, bem como das circunstâncias políticas que acompanharam a sua implementação.

Nas reflexões teóricas sobre a história constitucional ateniense ou sobre as formas de organização do poder político, as considerações relativas a códigos de leis e a legisladores ocorrem também com frequência, pois é através deles que a noção de politeia se concretiza. É nesse contexto que assumem grande importância algumas obras de Platão, Aristóteles e Teofrasto, ${ }^{21}$ bem como o esforço de compilação de 158 politeiai desenvolvido na esfera do Liceu. A avaliar pela Constituição dos Atenienses, que circula entre o corpus aristotélico, a informação que se perdeu foi de facto imensa, mesmo partindo do princípio de que estes trabalhos incidiam mais sobre questões de natureza política e constitucional e não tanto sobre matéria especificamente jurídica. Por outro lado, é certo que obras como a Retórica de Aristóteles poderão ter influenciado a actividade forense, mas esse influxo diria mais directamente respeito ao uso eficaz da techne rhetorike e não propriamente

21 Em parte já referidas (supra secção 2), mas às quais se poderiam acrescentar ainda, a título de exemplo, o Êutifron e a República para Platão e a Ética a Nicómaco para Aristóteles, na medida em que abordam problemas gerais de natureza moral e política, com incidência na aplicação da justiça. 
à prática jurídica. Por outras palavras, o facto de haver filósofos importantes que reflectiram sobre matéria com incidência legal não é garantia de que tenham, por isso mesmo, influenciado o pensamento jurídico grego, embora haja alguns indícios de que isso poderá ter acontecido. ${ }^{22}$

Ainda no âmbito da produção literária e artística, o teatro acaba por deter um papel igualmente significativo enquanto fonte para o conhecimento do direito grego, devido precisamente à sua natureza 'política', isto é, à conexão viva e empenhada que estabelecia com a realidade da pólis democrática ateniense, de que constitui simultaneamente reflexo, apologia e ponderação crítica. Essa realidade é visível, em particular, na comédia antiga, onde obras como as Vespas de Aristófanes colocam em cena uma paródia viva ao funcionamento dos tribunais atenienses. No caso da comédia nova, o enfoque desvia-se da pólis para o universo mais restrito da realização pessoal dentro do oikos, mas também aí certas questões legais assumem particular relevância, em especial na área do direito familiar: contratos matrimoniais, direitos de herança, paternidade e filiação, legislação relativa a casos de adultério, prostituição e violação, para mencionar apenas os casos mais evidentes. E embora nomes como Menandro surjam naturalmente ao falar-se de comédia nova, o facto de esta forma de produção dramática haver servido de modelo à comédia romana permite esperar que também o teatro de Plauto e Terêncio possa revestir-se de alguma relevância enquanto fonte para o estudo do direito grego - ainda que obrigue a uma atenção redobrada, por causa do processo de contaminação e de adaptação que a palliata romana operou sobre os modelos gregos utilizados. Pela mesma razão, será legítimo também o recurso a obras latinas que exploram controvérsias ou topoi retóricos de origem grega (como Séneca e Quintiliano), se bem que tenha de ser aplicada uma retracção metódica idêntica à referida para a palliata.$^{23} \mathrm{~A}$ tragédia grega tem sido usada com menor frequência para o estudo o direito ático, mas essa abordagem revela-se, na verdade, não apenas válida e pertinente, como pode inclusive iluminar de forma surpreendente a interpretação da obra dos grandes trágicos. ${ }^{24}$

22 Rossetti (2004), 53, sustenta que a obra de Teofrasto terá tido uma influência directa sobre a actividade legislativa do estadista Demétrio de Fáleron, que fora o discípulo mais famoso do sucessor de Aristóteles à frente do Liceu.

23 Vide Biscardi (1982) 33-35; Todd (1993) 42.

24 Como se pode constatar pela obra recente Law and drama in Ancient Greece, coordenada por Harris, Leão e Rhodes (2010). 
Contudo, é na obra dos oradores áticos que o coração da pólis pulsa com redobrada intensidade e, dado que nos discursos (reais ou fictícios) as leis constituem armas de eleição, é neles que se encontra, com maior abundância, matéria para reconstituir o sistema legal ateniense. ${ }^{25} \mathrm{~A}$ actividade dos dez oradores do cânone ocupa, em termos latos, a última parte do séc. V e todo o séc. IV, até ao termo da Época Clássica, facultando assim um retrato vívido da dinâmica judicial em plena democracia. Entre o corpus de obras conservadas sob o seu nome, detêm especial importância para o problema em análise os discursos forenses, que chegam a ultrapassar a centena de trabalhos. Uma vez que estes discursos procuram reproduzir, por escrito, discursos que terão mesmo sido proferidos, tornam-se muito expressivos da forma como a lei era aplicada em Atenas. No entanto, o que ganham em expressividade perdem, na mesma proporção, em objectividade, pois o objectivo do orador é convencer o auditório e ganhar a disputa, e não tanto estabelecer a verdade, tanto no que diz respeito a dados factuais como à própria interpretação das leis aduzidas. Por outro lado, como os discursos foram preservados por causa do seu interesse retórico-literário e não por serem uma fonte jurídica, o mais normal é não se conhecer a versão da parte contrária, nem o real desfecho do pleito, o que de facto acaba por limitar a correcta avaliação dos argumentos usados e o carácter genuíno das provas aduzidas. ${ }^{26}$

Por fim, no domínio literário há ainda a referir um tipo de contributos mais díspares, mas que podem, ainda assim, deter uma importância essencial para a elucidação de aspectos particulares das leis. Entram neste campo os comentários marginais (escólios) feitos a outras obras, em particular à

25 Em Portugal, começa a verificar-se também um interesse acrescido pela obra dos oradores. O estudo mais completo existente é uma abordagem de natureza sociológica, desenvolvido por Curado (2008) e centrado na imagem da mulher nos oradores áticos; Campos (2010) estudou e traduziu o Contra Leócrates de Licurgo. Nos próximos tempos, são esperadas novas abordagens e traduções comentadas da oratória ática, em linha de resto com a tendência verificada noutros países, em especial no mundo anglo-saxónico e em Espanha.

26 Só se conhece a versão exacta das duas partes litigantes em dois pares de discursos de Demóstenes (18 e 19) e de Ésquines (2 e 3) proferidos a propósito de duas importantes disputas que envolveram ambos os oradores: a embaixada a Filipe II da Macedónia e a atribuição de uma coroa de mérito a Demóstenes. Há ainda um discurso de [Lísias] (6) e outro de Andócides (1) que devem dizer respeito à mesma acusação central, bem como ainda mais dois discursos ([Demóstenes] 43 e Iseu 11), que também podem estar relacionados entre si. Vide Todd (1993) 37 e n. 13. 
produção dramática e ao trabalho dos oradores mais marcantes (Isócrates, Ésquines, Demóstenes) e ainda trabalhos de compilação e glossários, como os produzidos por Hesíquio, Fócio, Pólux e Harpocrácion, ou ainda a Suda, uma importante obra enciclopédica medieval de autoria desconhecida. Embora tardios e com um valor desigual, estes autores têm a seu favor o facto de haverem baseado o trabalho de erudição e recolha na pesquisa feita sobre uma ampla produção literária (em boa parte hoje perdida), de maneira que fornecem muitas vezes uma ajuda preciosa não só para a interpretação de termos técnicos, como ainda para recuperar partes de discursos que não se conservaram. ${ }^{27}$

A estes elementos de natureza literária, juntam-se ainda as provas documentais que a arqueologia e a epigrafia vão revelando e que se revestem, por vezes, de importância capital. É o caso, por exemplo, da lei sobre o homicídio atribuída a Drácon, que se conhece a partir de uma cópia feita em finais do séc. V e enquadrada num grande esforço de revisão legislativa, tarefa particularmente complexa que, por isso mesmo, tendo sido iniciada em 410, haveria de prolongar-se até aos começos do séc. IV. Foi ao abrigo deste programa que, logo numa primeira fase, se emitiu um decreto que autorizava a republicação da lei de Drácon sobre o homicídio. A data pode ser estabelecida com precisão, pois, à cabeça da inscrição, figurava o decreto com o nome do arconte epónimo (Díocles), cujo mandato cai em 409/8. Da cópia então feita e colocada na Ágora, em frente da Stoa Basileios, chegou até nós um fragmento substancial, que constitui, por este motivo, o documento mais significativo sobre as origens do direito criminal escrito, em Atenas. ${ }^{28} \mathrm{O}$ facto de, no Contra Macártato ([43].57), um discurso atribuído a Demóstenes, esta disposição aparecer igualmente citada, seguindo de perto o texto da inscrição de 409/8, constitui não apenas um precioso apoio para a sua reconstituição, como ainda faculta um elucidativo exemplo da forma

27 Harpocrácion, que reuniu um Léxico para os Dez Oradores, é a fonte para mais de metade dos fragmentos do corpus Lysiacum; e o livro oitavo do Onomástico de Pólux centra-se sobre terminologia legal e constitucional. Vide Dover (1968); Todd (1993) 43.

28 O texto publicado inicialmente por Köhler, em 1867, manteve-se durante um século como a edição de referência, até à altura em que Stroud estudou exaustivamente o original, conseguindo identificar mais 218 letras e fornecendo a leitura que desde então se impôs como sendo a melhor. A inscrição é analisada por Stroud (1968); Gagarin (1981); Gagarin (1986) 86-89, 109, 112-115. Pode encontrar-se a versão portuguesa da lei em Leão (2001) 345-346. 
como as fontes literárias e a epigrafia se podem combinar, de maneira a permitirem uma leitura mais apurada de uma determinada lei.

A única fonte existente com informação legal detalhada para uma outra pólis que não Atenas é o chamado Código de Gortina, que retira o seu nome de uma pequena cidade da ilha de Creta. Embora a 'amuralhada

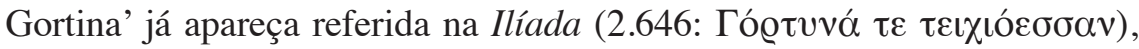
a sua fama provém da recuperação de uma extensa inscrição, com mais de seiscentas linhas, com informação muito importante para a área do direito de família e em especial para o estudo da situação legal da mulher. A datação da inscrição é controversa, embora se verifique um relativo consenso em considerá-la da primeira metade do séc. V a.C., se bem que haja quem sustente que possa retratar igualmente estádios mais anteriores da lei ${ }^{29}$ No entanto, porque esta reflexão sobre as fontes do direito se orienta especificamente para o estudo da lei em Atenas, a pertinência deste importante testemunho justifica-se apenas por comparação com a forma como situações análogas aparecem tratadas no direito ático. Representa, ainda assim, um elucidativo exemplo sobre o peso relativo das fontes quando se pondera o direito grego como um todo. Com efeito, as fontes literárias dominam claramente quando o objecto de estudo é Atenas, num claro sinal da vitalidade artística e cultural desta pólis democrática. No entanto, quando se ponderam outras cidades, a informação retirada de inscrições, papiros e mesmo legislação romana pós-clássica ganha evidente relevância. A situação ideal é poder conjugar esta informação de origem vária, fazendo-a confluir numa análise mais segura e mais vasta da jurisprudência grega. Trata-se, porém, de um desejo mais fácil de formular do que cumprir, já que são muitos os hiatos de informação que as fontes não permitem suprir. E mesmo que as fontes literárias e em particular a obra dos oradores sejam, no caso da Ática, o grande suporte da investigação, ainda assim resulta claro que um trabalho articulado entre juristas, filólogos, historiadores, epigrafistas e papirólogos é de extrema importância, em especial quando a análise evolui para além de uma perspectiva atenocêntrica - o que constitui, aliás, uma das tendências da crítica que deverá marcar a investigação nesta área do saber ao longo dos próximos anos.

29 Para um estudo e tradução da inscrição, vide entre outros Maffi (1997); Calero Secall (1997). Para uma análise crítica dos estudos mais recentes sobre o Código de Gortina, vide Maffi (2003). 


\section{Bibliografia citada}

BisCARDI, Arnaldo

- 1982: Diritto greco antico (Varese).

Calero Secall, Inés

- 1997: Leyes de Gortina (Madrid).

CAmpos, José António Segurado e

- 2004: "No tempo dos Decênviros: reflexões em torno da Lei das XII Tábuas e suas relações com o direito grego", in D. F. Leão, L. Rossetti e M. C. Fialho (eds.), Nomos. Direito e sociedade na Antiguidade Clássica/Derecho y Sociedad en la Antigüedad Clásica (Coimbra e Madrid), 297-350.

- 2010: Licurgo. Oração contra Leócrates. Tradução do grego, introdução e notas (Coimbra).

CAREY, C.

- 1997: Trials from classical Athens (London).

CAREY, Christopher e ReID, R. A.

- 1985: Demosthenes. Selected private speeches (Cambridge).

Curado, Ana Lúcia

- 2008: As mulheres em Atenas. As mulheres legítimas e as outras (Lisboa).

DOVER, Kenneth

- 1968: Lysias and the corpus Lysiacum (Berkeley).

GAGARIN, Michael

- 1981: Drakon and early Athenian homicide law (New Haven).

- 1986: Early Greek law (Berkeley).

HARris, Edward M., LeÃo, Delfim F. e Rhodes, P. J. (eds.)

- 2010: Law and Drama in Ancient Greece (London).

HARRISON, A. R. W.

- 1968-1971: The law of Athens. II vols. (Oxford).

KEnNEDY, George A.

- 1989: "Oratory”, in P. E. Easterling e B. M. W. Knox (eds.), The Cambridge history of classical literature (Cambridge), 86-114.

LEÃO, Delfim F.

- 2001: Sólon. Ética e política (Lisboa).

- 2005: "Sólon e a legislação em matéria de direito familiar”, Dike, n. s. 8, 5-31. 
- 2010: "The legal horizon of the Oresteia: the crime of homicide and the founding of the Areopagus", in E. M. Harris, D. F. Leão e P. J. Rhodes (eds.), Law and Drama in Ancient Greece (London), 39-60.

LeÃo, Delfim F., Fialho, Maria do Céu e Rossetti, Livio

- 2004: Nomos. Direito e sociedade na Antiguidade Clássica/Derecho y Sociedad en la Antigüedad Clásica (Coimbra e Madrid).

MacDowell, Douglas M.

- 1986: Spartan law (Edinburgh).

MAFFI, Alberto

- 1997: Il diritto di famiglia nel Codice di Gortina (Milano).

- 2003: "Studi recenti sul Codice di Gortina", Dike, n. s. 6, 161-226.

- 2004: "Gli studi di diritto greco oggi", in D. F. Leão, L. Rossetti e M. C. Fialho (eds.), Nomos. Direito e sociedade na Antiguidade Clássica/Derecho y Sociedad en la Antigüedad Clásica (Coimbra e Madrid), 33-49.

RHODES, P. J.

- 2004: "Keeping to the point", in E. M. Harris e L. Rubinstein (eds.) The law and the courts in Ancient Greece (London), 137-158.

RosSETTI, Livio

- 1999: "Aristotele, Teofrasto e la letteratura giuridica attica del IV secolo a.C.", Rivista Internazionale di Filosofia del Diritto 76, 651-682.

- 2004: "Materiali per una storia della letteratura giuridica attica", in D. F. Leão, L. Rossetti e M. C. Fialho (eds.), Nomos. Direito e sociedade na Antiguidade Clássica/Derecho y sociedad en la Antigüedad Clásica (Coimbra e Madrid), 51-73.

RUSCHENBUSCH, Eberhard

- 1966: Solonos Nomoi. Die Fragmente des solonischen Gesetzeswerkes mit einer

Text- und Überlieferungsgeschichte (Wiesbaden, reimpr. 1983).

STROUD, Ronald

- 1968: Dracon's law on homicide (Berkeley).

- 1979: The Axones and Kyrbeis of Drakon and Solon (Berkeley).

ToDD, S. C.

- 1993: The shape of Athenian law (Oxford). 